American Journal of Environmental Sciences 5 (4): 570-577, 2009

ISSN 1553-345X

(C) 2009 Science Publications

\title{
Full Scale Tests of Short-Term Municipal Solid Waste Incineration Bottom Ash Weathering Before Landfill Disposal
}

\author{
Franco Marchese and Giuseppe Genon \\ DITAG-Department Land, Environment and Geo-Engineering, \\ Politecnico di Torino, Corso Duca Degli Abruzzi 24, 10129 Torino, Italy
}

\begin{abstract}
Problem statement: Natural weathering is the most economic method of treatment in order to reduce the release of heavy metals present in the residue. Approach: The aim of the study was to optimize the minimum weathering times that were useful to reduce the lead release to within the Italian limits for landfill disposal. The mechanism of short-term weathering of MSWI bottom ash had been studied and its effect on the leaching of lead had been evaluated. Two bottom ash heaps had been realized for the experimental assessment: In one case an open-air situation was used, in the other, a heap placed under shelter was not exposed to rain. Results: The weathering course was monitored through the results of a leaching test that was carried out at different ageing times (EN 12457-2:2002). The total carbonates were also measured, at the same time, on the fine fraction of the weathered bottom ash $(<1 \mathrm{~mm})$. A fast decrease in lead release was observed in the analysis of the leachates and, at the same time, a decrease in $\mathrm{pH}$ and calcium concentration. The $\mathrm{pH}$ and leachate lead concentration control mechanisms were investigated and individuated. It had been possible to observe that the lead concentration was fundamentally a function of the $\mathrm{pH}$. The Calcite precipitation that occurred from calcium hydroxide carbonation was the main reason for the decrease above all during the first days of the process, when the maximum quantity of $\mathrm{CO}_{2}$ was fixed by air. The $\mathrm{pH}$ value was controlled by Portlandite dissolution only at the beginning, after the $\mathrm{pH}$ control seems to be due to aluminum hydroxides. Conclusion: The most significant changes in the bottom ash were found to occur in the first 60 days. It had been possible to verify the limited influence of washing phenomena while it was confirmed that carbonation was the most important process in short-term weathering and that it had an important rule on limiting lead release.
\end{abstract}

Key words: MSWI bottom ash, weathering, carbonation, lead release, leaching

\section{INTRODUCTION}

MSWI Bottom Ash (BA) can be used as secondary building material, in road sub-bases, in the construction of embankments and in other civil engineering applications as an alternative to landfill disposal. Bottom ash quality is carefully controlled for these applications: the potential leaching and release of some heavy metals and lead, copper, cadmium and zinc in particular represents the main problem for their reuse and disposal in landfills. In Italy, current legislation discourages reuse and BA is therefore generally disposed of in landfills, with or without pre-treatment.

The $\mathrm{pH}$ of MSWI bottom ash is usually slightly to strongly alkaline and it is therefore possible that the solubility of lead is quite high: The extraction of lead is in fact increased by high $\mathrm{pH}$ values ${ }^{[1-6]}$. The rate of lead release is one of main limitations, with reference to
Italian regulations, to the direct disposal of BA in nonhazardous landfills. Natural weathering is the most cost-effective treatment in the management of bottom ash disposal. Since MSWI bottom ash is fairly rapidly cooled after extraction from the kiln, the material is unstable under atmospheric conditions. Weathering changes the mineralogical characteristics of BA and its leaching behavior is therefore modified. One-to-three months' exposure to natural weathering is enough to reduce the release of heavy metals from $\mathrm{BA}^{[7-9]}$. The principal modification processes that have been reported during weathering are: Hydrolysis of oxides $(\mathrm{Ca}, \mathrm{Na}, \mathrm{K}, \mathrm{Al}, \mathrm{Fe})$; precipitation and dissolution of the hydroxides and salts of these main cations; carbonation; neoformation of clay like minerals from glass ${ }^{[9-11]}$. Carbonation involves the absorption of atmospheric $\mathrm{CO}_{2}$ by the initially alkaline $\mathrm{BA}$, with the consequence of a $\mathrm{pH}$ decrease and Calcite precipitation. Changes in

Corresponding Author: Giuseppe Genon, DITAG-Deprtment of Land, Environment and Geo-Engineering, Politecnico di Torino, Corso Duca degli Abruzzi 24, 10129 Torino, Italy Tel: 39-0115647660 Fax: 39-011564769960 
mineralogical forms and $\mathrm{pH}$ values are likely to affect the leaching of any major and trace elements. The effect of weathering on the leaching of heavy metals and particularly of lead leaching, mainly depends on three different causes: The first and most important is $\mathrm{pH}$ decrease as a consequence of carbonation; the second cause is immobilization by adsorption with $\mathrm{Fe}$ hydroxides ${ }^{[12]}$ : The last is the role of solid solution phenomena and particularly the possibility that lead traces are trapped in calcite deposits ${ }^{[13,14]}$. Carbonation and the oxidation of metals $(\mathrm{Al}, \mathrm{Fe})$ or organic substances are the first reactions in the initial phases of weathering ${ }^{[8]}$. The relevance of carbonation in shortterm natural weathering has been confirmed in some accelerated carbonation studies ${ }^{[15,16]}$. The aim of this study was to study the short term weathering phenomena for almost full-scale heaps, to verify the lead release trends and to individuate the best conditions to minimize the treatment times; the aim was to obtain a lower release than the concentration threshold $\left(1 \mathrm{mg} \mathrm{L}^{-1}\right)$ which is fixed by Italian law for non-hazardous waste landfill disposal.

\section{MATERIALS AND METHODS}

Experimental design: The experimental tests were performed in an MSW incinerator area in the NE of Italy during the Sep. 2007-Jan. 2008 period. The plant, which has three combustion lines equipped with air cooled grates, has a total capacity of about $70 \mathrm{kt} \mathrm{year}^{-1}$ and it is used to treat MSW, commercial wastes and, in two lines, hospital medical wastes. The quenched BA is about $22 \%$ by mass of the original waste, on a wet basis.

Two heaps were made with fresh BA. They measured $4 \times 12 \mathrm{~m}$ at the base and were $1 \mathrm{~m}$ high. Both heaps were built on a concrete floor area and a synthetic fabric was used for leachate drainage. This leachate was not collected during the tests but was directly conveyed to the draining systems adopted for plant process wastewater. One heap was constructed in the open-air, while the second was covered by a shelter, which was open at the sides. The heaps were in identical conditions but for the fact that the heap under the shelter was not exposed to rain: The humidity variations in this heap were only due to an evaporation process. The heaps were made of fresh BA, included grate siftings, that were obtained from only one of the three combustion lines (the BA flow rate was about $920 \mathrm{~kg} \mathrm{~h}^{-1}$ ), using material from three consecutive days. The ashes obtained from the entire production of each single day were mixed the following day and then divided into two parts, one for the open air heap and the other for the heap under the shelter. Each heap was therefore made up of three lots (I, II, III). The weathering study was then performed taking some representative samples of aged BA from the heaps at different exposure times: The ashes were subjected to the water leaching test (EN12457-2: 2002).

The initial characterization of fresh ashes was first defined for each material lot that had been used to build the heaps. The samplings were carried out on different lots at different ageing BA times and therefore referred to the initial characteristics of the corresponding lot ashes. The sampling times were $21,43,76$ and 110 days of real ageing. The heap ageing time was calculated from the first day after the corresponding lot heap had been built. The last sample (110 days) which was made up of a mixture that represented the three lots, was given the age of the intermediated lot (lot 2) as a reference. The meteoclimatic data were recorded throughout the entire test period. A schedule of the performed samplings and also some meteorological data of the weathering time intervals are reported in Table 1.

Sampling: In order to obtain a sample that can be considered representative with reference to the real exposition to atmospheric conditions, the BA drawings were performed by collecting all the material from 0.35 $\mathrm{m}$ cuttings taken from the whole trapezoidal section of the heap, which represented nearly $0.9 \mathrm{~m}^{3}$ of the heaped bottom ash. The geometric surface of this heap fraction in contact with the atmosphere was nearly $2.65 \mathrm{~m}^{2}$, with a surface/volume ratio of $1.8 \mathrm{~m}^{2} \mathrm{~m}^{-3}$. The geometric surface that is exposed to precipitations for the open-air heap corresponded to the plane projection of the previous surface and its value was nearly $1.45 \mathrm{~m}^{2}$.

All the BA was sieved to a dimension of $80 \times 80 \mathrm{~mm}$ : The passing fraction was homogenized and afterwards by the quartering it has been possible to realize samples for lab tests (about $30 \mathrm{~kg}$ each). The thus obtained BA samples were kept in a hermetically closed plastic tank overstuffed to avoid air contact and carbonation.

Tests and analytical methods: The bottom ash moisture was determined by drying all the samples at $105{ }^{\circ} \mathrm{C}$ for $24 \mathrm{~h}$. The bulk chemical composition was only measured on the initial BA samples before weathering by $\mathrm{X}$-ray fluorescence spectroscopy (Rigaku ZSX).

\begin{tabular}{llcc}
\multicolumn{4}{l}{ Table 1: Schedule of conditions of the heaps } \\
\hline $\begin{array}{l}\text { Period of } \\
\text { weathering (days) }\end{array}$ & Reference & $\begin{array}{l}\text { Temperature mean } \\
\text { of period }\left({ }^{\circ} \mathrm{C}\right)\end{array}$ & $\begin{array}{l}\text { Rain } \Sigma \text { of } \\
\text { period }(\mathrm{mm})\end{array}$ \\
\hline $0-21$ & II & 15.5 & 60.0 \\
$21-43$ & I & 11.2 & 34.4 \\
$43-76$ & III & 7.1 & 111.0 \\
$76-110$ & mix (I, II, III) & 3.4 & 180.0 \\
\hline
\end{tabular}


The carbonate evaluation was performed on the fine fraction $(<1 \mathrm{~mm})$ that had been obtained by sieving after drying the $\mathrm{BA}$ samples at $50^{\circ} \mathrm{C}$ in nitrogen current. The determination was based on the evaluation of the developed $\mathrm{CO}_{2}$ after acidification with $\mathrm{HCl}$.

The leaching test was performed on original samples without drying or any other pre-treatments; the EN12457-2:2002 test was used (one stage batch test at a liquid to solid ratio of $10 \mathrm{~L} \mathrm{~kg}^{-1}$, using demonized water). An amount of sample equivalent to $100 \mathrm{~g}$ of dry bottom ash per liter of water was placed in a widenecked plastic flask and slowly turned for $24 \mathrm{~h}$ at room temperature. After $24 \mathrm{~h}$ of equilibration, the final $\mathrm{pH}$ was recorded and the suspensions were filtered through $0.45 \mu \mathrm{m}$ membrane filters. Clear filtrates were divided into two samples. One sample was left untreated to measure the conductivity and alkalinity (carbonates) and for the analysis of chlorides and sulphates by ion chromatography. The second was acidified with concentrated $\mathrm{HNO}_{3}$ for the analysis of metals by AAS or GF-AAS.

\section{RESULTS}

Fresh quenched bottom ash: The chemical composition of the mean samples of fresh BA is reported in Table 2. The main element composition is in agreement with the literature ranges ${ }^{[4,7,11,17]}$, with the exception of calcium whose percentage in the studied BA was in fact higher. $\mathrm{Cu}, \mathrm{Zn}$ and $\mathrm{Pb}$ were the most concentrated of the trace elements.

The moisture and characterization of the leachates derived from the BA of the different lots are reported in Table 3.

The BA of the three lots presents almost the same moisture values. Some of the parameters of the leachate composition that arises from the leaching tests are quite similar, but others are rather different, for example, for lead.

Weathered bottom ash: In Fig. 1 it is possible to observe the variations in moisture of the two heaps during ageing.

The under-shelter heap presents a drying curve that almost exactly overlaps the theoretical prediction that can be calculated using the Turc formula with the starting point at the 21 st day of weathering. This consideration is an indication of the fact that during the first time interval a small leachate leakage occurred, while, in the following period, did not occurs.

As far as the open air heap is concerned, a positive net evaporation balance can be observed during the first time interval, while a water accumulation can be observed in the following period, particularly during the last period, in connection to the higher rain full (Table 1).
Table 2: Chemical composition of fresh quenched bottom ash (mean sample)

\begin{tabular}{lc}
\hline Element & Concentration $\left(\mathrm{mg} \mathrm{kg}^{-1}\right.$ dry w. $)$ \\
\hline $\mathrm{Si}$ & 161800 \\
$\mathrm{Ca}$ & 222000 \\
$\mathrm{Al}$ & 23100 \\
$\mathrm{Mg}$ & 39500 \\
$\mathrm{Fe}$ & 14100 \\
$\mathrm{Na}$ & 15100 \\
$\mathrm{~K}$ & 5900 \\
$\mathrm{~S}$ & 5100 \\
$\mathrm{Cl}$ & 9700 \\
$\mathrm{P}$ & 3900 \\
$\mathrm{Ba}$ & 2002 \\
$\mathrm{Mn}$ & 903 \\
$\mathrm{Cr}$ & 408 \\
$\mathrm{Ni}$ & 211 \\
$\mathrm{Cu}$ & 3063 \\
$\mathrm{Zn}$ & 2487 \\
$\mathrm{~Pb}$ & 1238 \\
\hline
\end{tabular}

Table 3: Moisture and composition of the leachate of the fresh BA before weathering $\left(\mathrm{mg} \mathrm{L}^{-1}\right)$

\begin{tabular}{lrrrr}
\hline & $\mathrm{T}_{0}$ lot I & $\mathrm{T}_{0}$ lot II & $\mathrm{T}_{0}$ lot III & \multicolumn{1}{c}{$\mathrm{T}_{0}$ mean } \\
Moisture (\%) & 24.30 & 24.40 & 24.90 & \multicolumn{1}{c}{24.50} \\
\hline $\mathrm{pH}$ & 12.50 & 12.57 & 12.53 & 12.54 \\
Conductivity & 5303.00 & 6550.00 & 6840.00 & 6200.00 \\
Carbonates & 64.00 & 45.00 & 64.00 & 54.00 \\
Chlorides & 233.00 & 282.00 & 347.00 & 287.00 \\
Sulphates & 0.43 & 2.17 & 2.02 & 1.65 \\
$\mathrm{Ca}$ & 490.00 & 448.00 & 493.00 & 473.00 \\
$\mathrm{Na}$ & - & - & - & 184.00 \\
$\mathrm{~K}$ & - & - & - & 93.30 \\
$\mathrm{Al}$ & 3.02 & 0.17 & 0.32 & 0.99 \\
$\mathrm{Cu}$ & 0.25 & 0.58 & 0.29 & 0.43 \\
$\mathrm{Zn}$ & - & - & - & 0.11 \\
$\mathrm{~Pb}$ & 5.76 & 8.51 & 4.62 & 6.88 \\
\hline $\mathrm{Co}$ & & & &
\end{tabular}

*onductivity $=\mu$ siemens

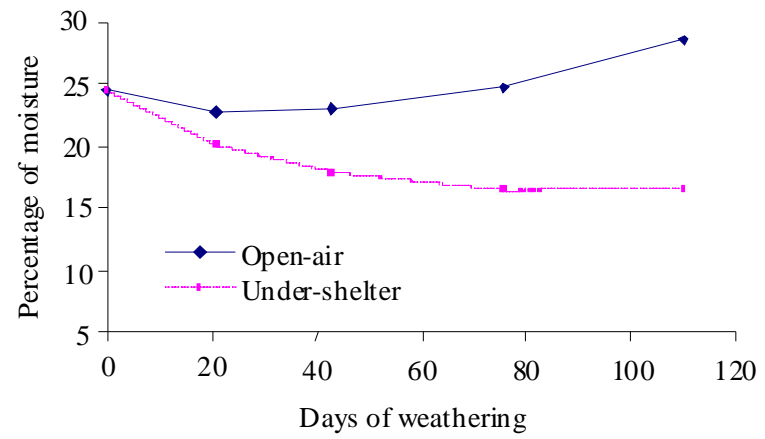

Fig. 1: Influence of weathering on the moisture of the heaps

Figure 2 shows the time behavior of the characterization of the leachates that have been obtained from the EN12457-2:2002 test on the BA samples extracted from the heaps after different weathering times. 
Am. J. Environ. Sci., 5 (4): 570-577, 2009
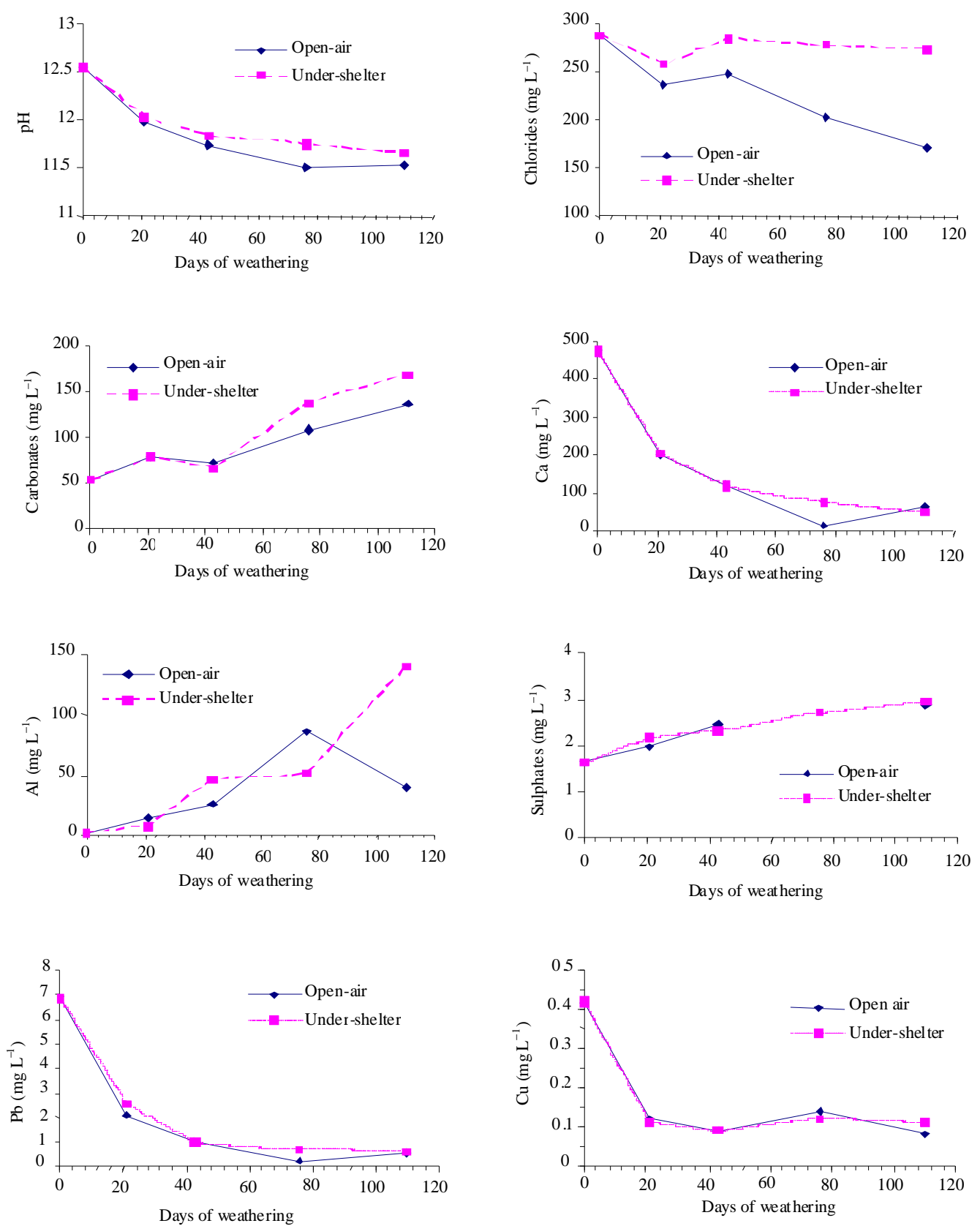

Fig. 2: Characterization of leachates of bottom ash at different weathering time

The $\mathrm{pH}$ values show a generally decreasing trend that is practically the same for the two heaps and corresponds to nearly $0.8 \mathrm{pH}$ units over 110 days of exposition. The progression instead seems slightly different, as it could correspond to washing phenomena in the open air heap. The chlorides trend, as expected, decreases for the open air heap, while it remains steady for the second heap, which was not exposed to rain. The decreasing trend of the calcium and the increasing trend of the carbonates confirm the presence of carbonation phenomenon ${ }^{[9]}$. The trends are similar for the two heaps, but the lower values that are registered at 76 and 110 days for the open air heap could be an index of soluble carbonates washing and/or of a lower capacity of $\mathrm{CO}_{2}$. A time increasing trend can be observed for aluminum and sulphates, which is in agreement with observations by other researchers ${ }^{[8,11]}$. 


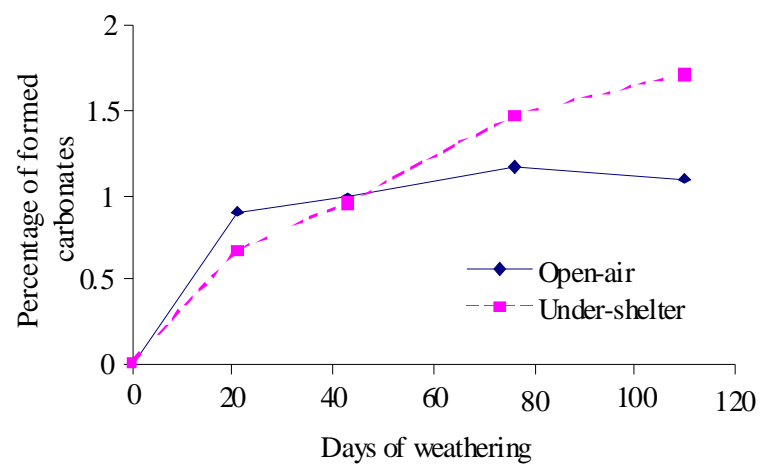

Fig. 3: Formation of carbonates during weathering

The highly decreasing trends for $\mathrm{Cu}$ and $\mathrm{Pb}$ after the first weathering period are also similar for the two heaps. The copper concentration then remained at steady values, with some fluctuations that are probably due to the organic dissolved content ${ }^{[3,12,18,19]}$ : This aspect was not investigated because of the limited interest of this element for leaching in relation to aims of this study. The lead concentration instead essentially depends on the leachate $\mathrm{pH}$. Unlike the observations of other researchers ${ }^{[8,12]}$, a quicker lead decrease than the $\mathrm{pH}$ variation, which could be an indication of sorption phenomena has not observed during the considered period.

Figure 3 shows the trend of the formed carbonates increase in the fine ash fraction $(<1 \mathrm{~mm})$ as a function of the weathering time.

\section{DISCUSSION}

The determination of a leachate saturation index with the main minerals leads to individuating which mineral phases are able to dissolve or precipitate. The saturation status of an aqueous solution is defined as:

$$
\mathrm{SI}_{\mathrm{M}}=\log \mathrm{Q}_{\mathrm{M}} / \mathrm{K}_{\mathrm{M}}
$$

Where:

$\mathrm{Q}_{\mathrm{M}}=$ The ionic activity product of mineral $\mathrm{M}$ in the water phase

$\mathrm{K}_{\mathrm{M}}=$ Its equilibrium constant

At equilibrium $\mathrm{K}_{\mathrm{M}}=\mathrm{Q}_{\mathrm{M}}, \mathrm{SI}=0$. If $\mathrm{SI}>0$, mineral $\mathrm{M}$ can precipitate while if $\mathrm{SI}<0$, mineral $\mathrm{M}$ can dissolve. From the calculation of the saturation indexes of the main significant minerals, with respect to the leachates derived from the leaching tests, it can be observed that the leachates are always oversaturated as far as the Calcite compound is concerned and, but only with reference to the $\mathrm{BA}$ leachates at the initial time (un-weathered BA), as far as Ettringite is concerned. These minerals can therefore precipitate in these conditions. The leachates instead are always undersaturated as far as Portlandite, Gibbsite and Gypsum, are concerned and which, if present, are subjected to dissolution. These results are partially in agreement with the observations of other researchers on outlet leachates ${ }^{[13]}$, during a weathering study conducted on a large heap. The obtained aluminum values are lower than the Gibsite and Boehemite solubility, but they are in good agreement with the solubility of microcrystalline Gibsite ${ }^{[20]}$, or have intermediated values between microcrystalline Gibsite and amorphous alumina. The aluminum concentration therefore seems to be controlled by microcrystalline Gibsite; this compound probably also has an important effect on the $\mathrm{pH}$ control. The $\mathrm{OH}^{-}$ion concentration in fact only depends on Portlandite dissolution at the initial leaching time (un-weathered BA), when the value of $\mathrm{pH}$ is over 12 , which is in agreement with the indications of some researchers ${ }^{[3,8,11]}$. The $\mathrm{OH}^{-}$ion concentration in the leachate of BA after 110 days of weathering could be consistent with the Ettringite solubility, while all the other leachates are in a status that is probably near equilibrium conditions for microcrystalline Gibsite. The calcium concentration is Portlandite controlled only in the zero time leachate, while, in the weathered BA leachates, it is too low to be controlled by the Portlandite or Gypsum dissolution, but too high to depend on the Ettringite dissolution; it therefore does not seem to be due to the dissolution of any of the considered minerals. It could depend on $\mathrm{CaCO}_{3 \mathrm{aq}}$ complex concentration, in agreement with the suggestions of some researchers ${ }^{[13]}$, when the system presents $\mathrm{pH}$ values near 12. The sulphates concentrations are two orders of magnitude lower than those observed by other researchers ${ }^{[11,12]}$, even for natural weathered BA with similar values of aluminum $^{[8]}$. A possible effect of Barium on the sulphates concentrations cannot be excluded on account of the quite high concentration of this element in fresh BA. Some researchers ${ }^{[8,12]}$ have observed unsaturated lead concentration values in leachates, with respect to Anglesite $\left(\mathrm{PbSO}_{4}\right)$, Cerussite $\left(\mathrm{PbCO}_{3}\right)$ and lead hydroxide. In this study, the leachates appeared undersaturated as far as Anglesite is concerned, but highly oversaturated with respect to Cerussite (Saturation Index range: 3.91-5.23). As for lead hydroxide, the result depends on the specific value of the solubility constant that is considered from among many literature values. Figure 4 shows the experimental values of the obtained lead concentration in comparison with the solubility curves that were calculated for different values of solubility product. 
Am. J. Environ. Sci., 5 (4): 570-577, 2009

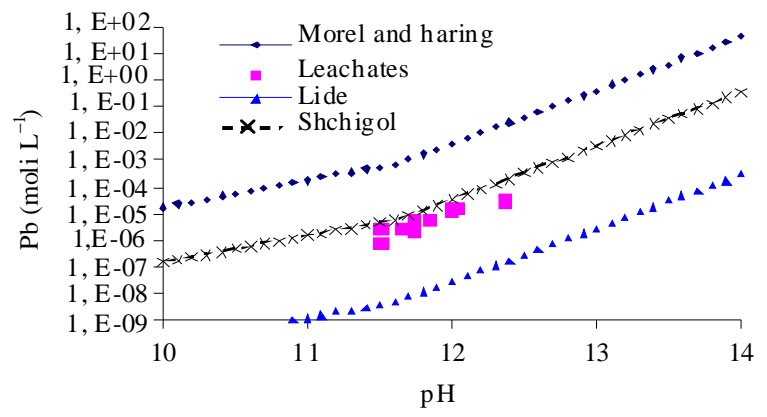

Fig. 4: Lead solubility: Experimental values and predictions

The obtained concentrations are clearly undersaturated, if we consider the Morel and Haring constant values $^{[21]}$, but oversaturated with respect to Lide's indications $^{[22]}$. If the Shchigol constant value ${ }^{[22]}$ had been used, the experimental values would have approximated the theoretical ones. It is therefore quite difficult to establish a clear under-saturation or oversaturation condition. However, the obtained concentration values are higher than those of the sorption equilibrium curve of surface complex formation of $\mathrm{Pb}$ onto goethite $(\mathrm{Pb}=\mathrm{FeOOH})$, as suggested by some researchers ${ }^{[12]}$. Apart from the absolute concentration values, the similarity of results, as a function of $\mathrm{pH}$ in comparison with the theoretical ones, seems to be an indication of the prominent role of this parameter on the control of lead concentration. The $\mathrm{pH}$ decrease is due to Portlandite carbonation. The carbonation mechanism is defined from $\mathrm{CO}_{2}$ water absorption and then from the carbonation reaction in the aqueous phase.

The main reaction is ${ }^{[3,23]}$ :

$$
\mathrm{Ca}(\mathrm{OH})_{2(\mathrm{aq})}+\mathrm{CO}_{2(\mathrm{aq}) \rightarrow} \mathrm{CaCO}_{3}+\mathrm{H}_{2} \mathrm{O}_{(\mathrm{l})}
$$

It can be observed (Fig. 3) that the most important carbonates increase is obtained during the first time interval. This fact is also in agreement with the trends that can be observed in fast carbonation processes operating on similar materials ${ }^{[24]}$ and it can be justified by the high values of the initial moisture and alkalinity. In the open air heap the higher initial carbonation is probably supported by the mean moisture value of the period where the parameter is at its maximum value ${ }^{[8,24]}$. The carbonates percentage in the solid phase can decrease both on account of the soluble carbonates washing and of the soluble hydroxides dissolution, leading to the impossibility of fixing new $\mathrm{CO}_{2}$. However, the carbonation level during the first period seems to be sufficiently high to avoid the control of leachates $\mathrm{pH}$ from $\mathrm{Ca}(\mathrm{OH})_{2}$. Some researchers ${ }^{[14]}$ have highlighted the prominent role of solid solution, in comparison with the surface sorption of hydroxides. Most of the minerals identified in the aged bottom ash (carbonates, sulphates) have a high trace element trapping capacity. The hypothesis of Calcite trapping of $\mathrm{Pb}(\mathrm{Zn}, \mathrm{Cd})$ traces, in agreement with accelerated carbonation tests that show complete $\mathrm{Pb}$ and $\mathrm{Zn}$ trapping ${ }^{[15]}$, should be considered it cannot be excluded that the significant decrease in lead subjected to dissolution that has been obtained in this study also depends on this mechanism, as was observed by one of the researchers of this study during a previous weathering experimentation on BA from different incinerators ${ }^{[6]}$.

\section{CONCLUSION}

The study has confirmed that the short-term weathering of MSWI bottom ash for 60-90 days before its disposal is a satisfactory solution that could be useful to diminish lead release: It has also been demonstrated that the lead concentration of leachates primarily depends on the $\mathrm{pH}$. In the short term the carbonation of calcium hydroxides is the main reaction that controls the $\mathrm{pH}$; in fact, after 21 weathering days, the $\mathrm{pH}$ is not longer controlled by $\mathrm{Ca}(\mathrm{OH})_{2}$ (Portlandite) dissolution. The $\mathrm{pH}$ control at different weathering steps seems to be connected to aluminum hydroxide (amorphous and mycrocristalline Gibsite); only after 110 days of weathering did a potential participation of Ettringite equilibrium arise. In spite of the large reduction in the lead concentration values of the leachates, the solution system was always oversaturated as far as Cerussite is concerned and conditions near to equilibrium were obtained for the lead hydroxides. This fact probably indicates the absence of the adsorption of lead onto Goethite, while the release of lead involved in Calcite precipitation or in other neoformation phenomena of secondary minerals seems to be a possible mechanism.

As the trends versus time of the $\mathrm{pH}$ and of the concentration values of calcium and lead were similar for the two heaps, whether in the open air or under shelter, the phenomenon of rain washing seems to be less important even through the precipitations were fairly high during the test period. Carbonation seems to be the controlling aspect especially during the first process days. The efficiency of the carbonation process, taking into account the constant value of the $\mathrm{CO}_{2}$ partial pressure, depends on the moisture and temperature of the ash heap and above all on the specific surface that is available for gas exchange.

If a scale-up of the system is considered, it is necessary to take into account the fact that an excessive 
dimension increase in the heaps could lead to an increase in temperature inside the mass, with a consequent decrease in carbonation efficiency.

\section{REFERENCES}

1. Van Der Sloot, H.A., R.N.J. Comans and O. Hjelmar, 1996. Similarities in the leaching behavior of trace contaminants from waste, stabilized waste, construction materials and soils. Sci. Total Environ., 178: 111-126. DOI: 10.1016/00489697(95)04803-0

2. Quevauviller, P.H., H.A. Vander Sloot, A. Ure, H. Muntau, A. Gomez and G. Rauret, 1996. Conclusions of the workshop: Harmonization of leaching/extraction tests for environmental risk assessment. Sci. Total Environ., 178: 133-139. http://cat.inist.fr/?aModele $=$ afficheN\&cpsidt $=2968968$

3. Meima, J.A. and R.N.J. Comans, 1999. The leaching of trace elements from municipal solid waste incinerator bottom ash at different stages of weathering. Applied Geochem., 14: 159-171. http://cat.inist.fr/?aModele $=$ afficheN\&cpsidt $=1687142$

4. Sabbas, T., A. Polettini, R. Pomi, T. Astrup and P. Lechner et al., 2003. Management of municipal solid waste incineration residues. Waste Manage., 23: 61-88. DOI: 10.1016/S0956-053X(02)00161-7

5. Marchese, F., M. Poggio, D. Quaranta and G. Giusti, 2004. Characterization of the release of MSWI bottom ash. RS. MILANO., 18: 86-92. http://direct.bl.uk/bld/PlaceOrder.do?UIN=157992 $604 \&$ ETOC $=$ RN\& from $=$ searchengine

6. Marchese, F., M. Poggio and G. Giusti, 2005.Weathering of MSWI bottom ash heap. RS. MILANO., 19: 294-304. http://direct.bl.uk/bld/PlaceOrder.do?UIN=176829 230\&ETOC $=$ RN\& from $=$ searchengine

7. Wiles, C.C., 1996. Municipal solid waste combustion ash: State of the knowledge. J. Hazardous Mater., 47: 325-344. http://cat.inist.fr/?aModele=afficheN\&cpsidt=3058665

8. Chimenos, J., A.I. Fernandez, R. Nadal and F. Espiell, 2000. Short-term natural weathering of MSWI bottom ash. J. Hazard. Mater., 79: 287-299. DOI: 10.1016/S0304-3894(00)00270-3

9. Chimenos, J.M., A.I. Fernandez, L. Miralles, M. Segarra and F. Espiell, 2003. Short-term natural weathering of MSWI bottom ash as a function of particle size. Waste Manage., 23: 887-895. http://cat.inist.fr/?aModele $=$ afficheN\&cpsidt $=15267665$

10. Belevi, H., D.M. Stampfli and P. Baccini, 1992. Chemical behavior of municipal solid waste incinerator bottom ash in monofills. Waste Manage. $\quad$ Res., 10 153-167. http://cat.inist.fr/?aModele=afficheN\&cpsidt=5360351
11. Meima, J.A. and R.N.J. Comans, 1997. Geochemical modeling of weathering reactions in municipal waste incinerator bottom ash. Environ. Sci. Technol., 31: 1269-1276. http://cat.inist.fr/?aModele $=$ afficheN\&cpsidt $=2655$ 945

12. Kersten, M., H.Ch. Moor and C.A. Johnson, 1997. Speciation of trace metals in leachate from a MSWI bottom ash landfill. Applied Goechem., 12: 675-683.

http://cat.inist.fr/?aModele=afficheN\&cpsidt=2062 286

13. Freyssinet, PH., P. Piantone, M. Azaroual, Y. Itard and J.C. Baubron, 2002. Chemical changes and leachate mass balance of municipal solid waste bottom ash submitted to weathering. Waste Manage., 22: 159-172.

http://cat.inist.fr/?aModele $=$ afficheN\&cpsidt $=1355$ 6918

14. Piantone, P., F. Bodenan and L. Chatelet-Snidaro, 2004. Mineralogical study of secondary mineral phases from weathered MSWI bottom ash: Implication for the modeling and trapping of heavy metals. Applied Geochem., 19: 1891-1904. http://cat.inist.fr/?aModele $=$ afficheN\&cpsidt $=1630$ 4384

15. Bodenan, F., M. Azaroual and P. Piantone, 2000. Forecasting the Long-Term Behavior of Municipal Solid Waste Incineration Bottom Ash: Rapid Combined Tests. In: Waste Material in Construction, Woolley, G.R., J.J.J.M. Goumans and P.J. Wainwright, (Eds.). Elsevier, Amsterdam, USA., ISBN: 0080437907, pp: 1064.

16. Polettini, A. and R. Pomi, 2004. The leaching behavior of incinerator bottom ash as affected by accelerated ageing. J. Hazard. Mater., B113: 209-215. http://www.ncbi.nlm.nih.gov/pubmed/15363533

17. Hjelmar, O., 1996. Disposal strategies for municipal solid waste incineration residues. $\mathrm{J}$. Hazard. Mater. $\quad$ 47: 345-368. http://cat.inist.fr/?aModele=afficheN\&cpsidt=3058666

18. Johnson, C.A., M. Kersten, F. Zeigler and H.C. Moor, 1996. Leaching behavior and solubility controlling solid phases of heavy metals in municipal solid waste incinerator ash. Waste Manage., 16: 129-134. http://cat.inist.fr/?aModele $=$ afficheN\&cpsidt $=2537$ 809

19. Meima, J.A., A. Zmoren van and R.N.J. Comans, 1999. Complexation of $\mathrm{Cu}$ with dissolved organic carbon in municipal solid waste bottom ash leachates. Environ. Sci. Technol., 33: 1424-1429. http://cat.inist.fr/?aModele $=$ afficheN\&cpsidt $=1802$ 371 
20. Perkins, R.B. and C.D. Palmer, 1999. Solubility of ettringite. Geochimica et Cosmochimica Acta 63, 1969-1980. DOI: 10.1016/S0016-7037(99)000782

21. Morel, F.M. and J.G. Hering, 1993. Principles and Applications of Aquatic Chemistry. Wiley-Inter Science, New York, ISBN: 0471548960, pp: 588.

22. Sun, Z.H. and R.O. Skold, 2001. A multiparameter titration method for the determination of formation $\mathrm{pH}$ for metal hydroxides, Miner. Eng., 14: 1429-1443.

http://cat.inist.fr/?aModele $=$ afficheN\&cpsidt $=1411$ 3084
23. Meima, J.A. and R.N.J. Comans, 1998. Application of surface complexation/precipitation modeling to contaminant leaching from weathered municipal solid waste incinerator bottom ash. Environ. Sci. Technol., 32: 688-693.

http://cat.inist.fr/?aModele $=$ afficheN\&cpsidt $=2192$ 055

24. Rendex, E., G. Ducom and P. Germain, 2006. Carbon dioxide sequestration in Municipal Solid Waste Incinerator (MSWI) bottom ash. J. Hazard. Mater., 128: 73-79.

http://cat.inist.fr/?aModele $=$ afficheN\&cpsidt $=1742$ 2342 